\title{
Engagements, grammars, and the public: From the liberal grammar to individual interests
}

This is the post print version of the article, which has been published in European Journal of Cultural and Political Sociology 5(1-2), 42-65. 2018

Veikko Eranti (University of Tampere), veikko.eranti@gmail.com / @veikkoeranti

Please find the published version of this paper at

https://www.tandfonline.com/doi/full/10.1080/23254823.2018.1442733

\begin{abstract}
This article explores the role of individual interests within the pragmatic sociology of engagements expounded by Laurent Thévenot. He developed the idea of multiple regimes of engaging with the world - cognitive models of information-processing and what kind of good is engaged in different situations. In this article I argue that the way the sociology of engagements is currently formulated does not sufficiently allow for analysing public participation and disputes in situations where individual interests play a crucial role in public debates. The article presents a slight reformulation of what Thévenot calls the grammar of individuals in a liberal public (sic), based on a) an understanding of how individual interests relate to the common good and general will, b) the constitution of legitimate actors within polities, and c) the separation between the levels of generality and publicity. This reformulation might be called the grammar of individual interests, clarifying and simplifying earlier terminology .
\end{abstract}

\section{Keywords:}

social theory, sociology of engagements, individual interests, individuals, political sociology, pragmatic sociology

\section{Acknowledgements}

This author wishes to thank Laurent Thévenot, Eeva Luhtakallio, Tuukka Ylä-Anttila, Tomi Lehtimäki, Turo-Kimmo Lehtonen, Risto Heiskala, Tuomas Ylä-Anttila, Markku Lonkila, and Irina Raposova, Adam Gajdos and other participants in the Politics of Engagement Colloqium in Helsinki 2017, as well as two anonymous reviewers and numerous copyeditors for all their helpful comments during different stages of the process that ended up as this paper. 


\section{Introduction: pruning for the public eye}

Laurent Thévenot's pragmatic sociology provides us with a good set of tools for understanding how disputes and conflicts can be solved peacefully in a complex world - a toolkit that can be used cross-culturally in a comparative manner. But the role of individual interests has thus far been underdeveloped in this framework. This article aims at clarifying the role of individual interests - 'the grammar of individuals in a liberal public ' (Thévenot 2014 , 2015)- within what is often called French pragmatic sociology, the sociology of engagements, and justification theory.

Laurent Thévenot's efforts - including his earlier works with Luc Boltanski towards understanding how individuals coordinate their lives and resolve conflicts in complex societies, has given rise to many fruitful empirical analyses of the use of the common good in public debates (Ylä-Anttila \& Luhtakallio 2016), of the populist appropriation of emotionally charged commonplaces (Ylä-Anttila 2016), and also of the ways in which different valuations can be used within a single conflict (Eranti 2017). Justification theory (Boltanski \& Thévenot 2006[1999]) and the Sociology of Engagements (Thévenot 2007, 2015) offer us a finely nuanced set of concepts that can be operationalised to understand how individuals connect to the material world, coordinate action, resolve conflicts - and build commonality with other people. Justification theory, based on the idea that there is a limited number of ways of constructing the common good that are used by actors in discussions and in conflicts, lends itself naturally to the analysis of democratic participation. But if we wish to use the broader sociology of engagements (which incorporates ways of acting that are not based on the common good) in analysing participation, disputes, and confrontations in analysing public debates, some clarifications and developments to the theoretical foundations are needed.

This is certainly true for the grammars of commonality and regimes of engagement presented by Thévenot $(2001,2007,2011,2014,2015)$, a typology of action grounded in the pragmatist idea of different ways in which individual actors relate to the (physical) world. There are three (main) types of engagement with the world: one based on public justifications, one based on familiar, close affinities and one based on individual interests. When these three engagements operate in public, that is, on the level of political argumentation, Thévenot $(2014,2015)$ calls them grammars of commonality. The grammar incorporating individual interests, 'Individuals in a liberal public', is built upon the regime of 
the plan - on the codified intentionality of actors and their capacity to project their will into the future. While this definition has merits, it also limits analytic potential in situations that resemble public political discussion more than private arrangements. In this paper I argue that without partial reworking, the theory does not adequately capture political claims and critique based on individual interests.

Many strands of social theory start from the assumption that individual interests are what drive people, and that thus they are always the most legitimate arguments one can make. The value of the pragmatic sociology approach is that it can potentially treat individual interests as just one possible way of presenting critique and solving conflicts. Here I construct a version of pragmatic sociology that simultaneously retains the commitment to analysing common goods and ways of conflict resolution, and brings the role of individual interests on a par with the other grammars.

Some of the critiques presented here use ideas from the study of deliberative democracy and participation to highlight the problematic places within this theoretical framework. My aim is to provide alternative interpretations, especially about the role of individual interests, that are needed to use the sociology of engagements naturally as a theory of disputation within diverse democratic situations. The article focuses on using pragmatic sociology in the context of democratic participation and public disputes, which is not the only way to interpret or to operationalise the theory, but nonetheless is the one that promises the greatest empirical benefits. This move from the philosophical and anthropological levels of the original theoretical works towards more public-oriented political sociology has already been carried out in many empirical studies (Eranti 2017, Luhtakallio, 2012, Ylä-Anttila 2010b and Tuukka Ylä-Anttila 2016, Ylä-Anttila \& Luhtakallio 2016, Gladarev \& Lonkila 2013, YläAnttila \& Kukkonen 2015, Ylä-Anttila et al. forthcoming, Eranti 2014, Eranti 2016).

This paper aims at doing some pruning around the relation between justifications, individual interests and the general will, in the context of public participation and discussion. Examples and quotations are taken from a participatory urban planning process in Helsinki, better detailed in my earlier work (Eranti 2017 and 2014). How does the concept of legitimacy (in the sense of being accepted as argumentation within a polity) work with comments not based on the common good? To answer this question, we must also engage with questions of commonality and generalisability: the grammar of 'individuals in a liberal public' (as presented by Thévenot 2014, 2015) is seen as being on a lesser level of 
publicity and on a lower level of abstraction than the grammar of public justification. Justifications operate on the level of principles, of abstract common goods put to the test in particular situations. Because these goods are abstract, and by definition based on common humanity, they are available for everyone as a repertoire of actions and rhetoric (see Swidler, 1986; Silber, 2003). If the aim is to understand how argumentation by reference to individual interests is used in disputes, we need to understand the limits of the legitimacy concerned and in order to do this, we must think these aspects of the 'grammar of individuals in a liberal public' anew. I propose that this grammar should be called the grammar of individual interests to make its constituting feature more evident, and to distance it from reference to the unclear and polysemic concept of liberalism. ${ }^{1}$

The next section starts by analysing the role of the common good and the general will, through presenting key ideas of justification theory and their relation to pragmatist creativity. Then I proceed to the idea of multiple ways of engaging with the world, and how they are operationalised in public as grammars of commonality. The rest of the paper is devoted to analysing the role of individual interests within this theoretical framework. Concluding remarks take the form of questions about the nature of the polity, and the nature of politicisation in a world where arguments based solely on individual interests are legitimate.

\section{Public justifications and the general will}

In On Justification, Boltanski and Thévenot (2006) present six orders of worth - common goodbased justifications which can be and are deployed to solve conflict situations without degenerating into more primitive means of resolution. These are Market worth, where evaluation is based on monetary worth; Industrial worth, in which efficiency and measurability are valued; Civic worth, where the emphasis is on solidarity and collectivity; the order of Fame, where popularity, fame and renown are valued; Inspiration, in which evaluation is based on grace, spirituality and individual creativity; and Domestic worth, valuing tradition, esteem and somewhat hierarchical arrangements. A later addition, Green worth, places value on biodiversity and nature (see Lafaye \& Thévenot 1993).

\footnotetext{
1 What I propose here is to rename a theoretical category, while at the same time reworking some of the ideas included. Whether it would be more suitable to understand what I present here as a distinct category in itself, while keeping the original formulation unchanged, is a question I leave to future debate.
} 
What are these justifications? Human beings have a critical capacity - a capacity to justify their positions, to challenge existing structures and situations (Boltanski 2011, Boltanski \& Thevenot 2006, 1999). If this capacity were completely creative, flexible, and free, arguments would often be complete gibberish, and compromise between parties in a dispute would be all but impossible - as would sustaining a common society. ${ }^{2}$ Justifications can be seen as shared sets of cultural repertoires (Silber 2003, Swidder 1986). This means that they must be recognisable by others, lest communicating (both in the normal sense, and in the specific way Thévenot uses it in 2011, 2015: making things common) should become impossible.

The critical capacity arises especially in moments of crisis, when the status quo is disrupted (Boltanski \& Thévenot 1999). This crisis can be seen as a special case of situation, as used by pragmatists (Joas 1996, Dewey 2006[1927], Kilpinen 2009): a situation occurs when actors have to make choices, either to follow known paths, or to adopt creative strategies. All meaningful, non-routine action happens in these kinds of situations. This leads Hans Joas to classify pragmatism as a theory of situated creative action (1996:132). The special emphasis of this kind of pragmatist creativity shows when Boltanski and Thévenot are compared to Bourdieu (Boltanski 2011), which was their initial point of divergence: rather than following clear-cut paths of action deriving from habitus or class position, actors have a critical capacity of their own (for more on situated, creative political action, see Eranti 2016: 14-26).

In these kinds of crisis situations, the actors will take recourse to certain cultural repertoires (Swidler 1986, Silber 2003). These repertoires are dynamic and local, but not random. They can be called institutionalised habits (Ylä-Anttila 2010a,). As noted earlier, the six justifications presented in On Justification (Boltanski \& Thévenot 2006) are cultural repertoires of evaluation: each order of worth forms a scale, with which things, people and arrangements can be evaluated based on a shared principle (cf. Lamont 2012, Lamont \& Thévenot 2000, with On justification, 140-141; see also Eranti 2017).

The model of an order of worth, presented in On Justification, includes more than just the common good, or a principle of evaluation. Individuals, as well as non-human things and arrangements, can be ordered according to a set of principles of the common good. These orderings are always temporary; they change according to situation and according to the

\footnotetext{
2 Thévenot in his later works builds a picture of a pluralistic, not an atomistic society - and this difference is related to having a discrete but large number of possible justifications.
} 
arrangement of material objects. This ordering is what allows us to resolve conflicts. Since the basis of the ordering is supposed to be shared and generally understood, all parties to the conflict can, once the ordering is decided upon, agree on it as the basis of the compromise or solution. The importance of material objects and qualified non-human actors as belonging to the justifications, as well as the empirical focus, distinguish justification theory and thus Boltanski and Thévenot from Walzer, another author who developed similar ideas about the communal and disputed nature of the common good (Ricœur 2000, 86, Wagner 1999).

To understand how the idea of individual interests, as a legitimate basis for conflict-resolution and a starting point for democratic participation, relate to the framework of justifications based on the common good that has been presented, we need to take a closer look at the civic order of worth. In the civic order, the relevant questions are those of solidary and egalitarian principles. In the civic order, where the evaluation is based on collective interest and solidarity, legitimate arguments are those based on justice and fairness on the collective level, not from the perspective of individual rights. In the civic world, collectives are valuable as such (On Justification, 185-186).

The civic generality is one where all relations, if they are to be considered legitimate, must be made publicly known with 'reference to the collective entities (...) that ground their general interests' (On Justification: 11). ${ }^{3}$ Here, the common good does not arise as a sum of individual wills, but rather as a collective thing in itself, above those private interests. This, while most evident in the civic order, holds true for all of the orders of worth. Each order of worth is dependent on a definition of a common good, and while this is not the same as being dependent on the concept of general will, it leans in that direction: it is hard to think of the common good without some conception of a unified body politic, without something that puts the 'common' into the common good. This is how the general will manifests itself.

All orders of worth in On Justification are based, in addition to ethnographic fieldwork and interviews, on historical and canonical philosophical texts. The historical text for the civic worth is in Rousseau's The Social Contract (1762). In this work, the will of a Sovereign (a monarch, or perhaps The People in the streets) acts as the model for the general will, rising (quite literally) above individual concerns. This line of thinking permeates all

\footnotetext{
${ }^{3}$ See also Ricœur, 2000.
} 
orders of worth. ${ }^{4}$ Within public justifications, all evaluation is thus dependent on a shared conception of what is good, of evaluative thinking that starts from the community, or general will, and not from the individual.

Boltanski and Thévenot focus on interactions between people and objects on the abstract and personal level - on theoretical texts and in interaction situations. Their focus is not on public justification. Actually, in their work, the concept of the public hardly figures at all, even though some elements of justification are stated to happen within the context of a Habermas-style public sphere (Habermas 1991, Boltanski 2011, Lamont \& Thévenot 2000 also in On Justification).

Luhtakallio and Ylä-Anttila (Ylä-Anttila \& Luhtakallio 2016, Luhtakallio 2012, Ylä-Anttila 2010b) have developed operationalisations of the theory focused on explicitly analysing public justification. They aim at providing a clearly-defined method of describing usage of the common good in media debates, by combining justifications with the political claims analysis, developed by Koopmans \& Statham (1999) to analyse protest events and political claims presented in them. A justification is the use of orders of worth to back a claim presented in a public discussion. The resulting method recognises different usages of justifications (critique, compromise, claims-making) and different types of actors (NGOs, individual citizens, states). The justifications themselves are not amended significantly: they are readily available and usable for this kind of analysis.

\section{From justifications to engagements to grammars}

After On Justification, Laurent Thévenot focused on recognising different types of action, and how they relate to justifications, public discussion and political action. While On Justification is a forceful work, some types of critiques and actions could clearly be analysed more deeply using a vocabulary that extends beyond the common good.

One of the most important pointers in this direction came from the comparative work Laurent Thévenot did with Michèle Lamont (Lamont \& Thévenot 2000, Thévenot \& Lamont 2000 - see also Thévenot 2014:9), where clear differences in construction of the public good, and the importance and legitimacy of individuals and their preferences, were

\footnotetext{
${ }^{4}$ I do not want to push this point too far: there are so many nuances of individual polities (as they are called in On Justification) and orders of worth that a direct one-to-one correlation is not easy to show. I argue that it is actually not necessary either: even if the link is vaguer, it still helps us, like an archetype, to see how argumentation based on individual interests is different from the grammar of public justification.
} 
shown between the US and the French polity (Moody \& Thévenot 2000, Thévenot, Moody \& Lafaye 2000). Justification theory is focused on different models of common goods, and all the justifications are, by definition, collective. Thus, references to the private interests of the actor, though numerous in empirical situations, cannot easily be incorporated into justification analysis - for this type of debate is not always about monetary worth or the functioning of the markets, even if these ideas are closely related to the concept of individual interest.

Thévenot's solution was to present three types of cognitive format and ways of engaging with the material world, which are then related to three general types of presenting arguments and solving conflicts, called grammars (for engagements, Thévenot 2001, 2007, and for grammars, see Thévenot, 2011, 2014, 2015).

In this section, I provide an overview of the pragmatic regimes of engagements (Thévenot 2001, 2007), and how these cognitive models become social: how they are enlarged to matter on a societal level. My critical re-evaluation and re-building of the argument is focused on this operation of enlarging.

Influenced by practice theory, Thévenot developed pragmatic regimes as 'social devices which govern our way of engaging with our environment inasmuch as they articulate two notions: a) an orientation towards some kind of good; b) a mode of access to reality' (Thévenot 2001, 75). Engagements are ways of relating to the (physical) world, which entail how the actor handles information, is engaged with certain objects, and the good that is best pursued by doing this. Thévenot $(2001,2007)$ hardwires certain cognitive modes into achieving certain kinds of goods.

As there are multiple goods to be pursued (familiar enjoyment of the surroundings, intentionality and 'projecting oneself into future', publicly justified principles), there are also multiple ways of engaging with the material world. The idea of three different regimes opens the possibility of different criteria for valuation (see Lamont 2012). So, in addition to the cognitive formats and relation to the material environment, the mode of evaluation also plays a crucial role.

On Justification presented the level of justifiable public action, where arguments, people, and arrangements are general, based on a higher common principle of evaluation, and rely on the concept of general will. This level is by definition somewhat abstract: for an argument to be based on common goods, the great majority of all details and personal 
attachments have to be left out. In this type of action, or argumentation, there are no places for intimate arrangements or for giving special attention to loved ones - or for the expression of pure self-interest. In addition, Thévenot proposed two other regimes of engagements that are below the level of abstraction of the regime of publicly justifiable action. These regimes of engagements are the regime of familiarity and the regime of planned action. I shall first present these regimes, and then engage in a critical re-reading of the regime of the plan.

In the regime of publicly justifiable action, all evaluation is based on abstractlevel common good. Action is 'oriented to the demands of public order' and 'evaluation must be valid for a third party and characterized by generality and legitimacy' Thévenot (2007, 417). The central elements are the qualifications that people and assemblages receive, and the ordering that is possible because of these qualifications.

The regime of familiarity is on the 'lowest' level, most intimate and most dependent on the personal. The central good is familiarity and a feeling of ease, emotions are expressed and emotional attachment to people, objects, and places are cherished. The relation to objects is central in all regimes, but it gains special heft in the familiar engagement. One feels at ease in one's home neighbourhood, when one almost intuitively knows where everything is, has an emotional attachment to many of the objects surrounding daily routines (trees, rocks, little nooks and crannies in paths), and constructs personal arrangements (what side of the road is usually taken, which coffee-shop one visits, where one jogs). Pleasure is derived from these routines and habitual actions.

For the third leg of the triad, Thévenot presents a regime that relies on intentionality, conventional action, and the ability to fulfil plans, the regime of the plan. This was meant in a limiting sense: not all human action seeks to fulfil specific plans, and thus individual interests (which are realised through such intentionality) are, in this theoretical context, not the sole or overarching goal of human action. They are in focus only in this limited engagement (Thévenot 2001, 69-71). It is the way of engaging with the world that aims at changing the status quo.

In the regime of the plan, disputes are meant to be resolved through brokering deals, and in a kind of naturally appearing barter. When this becomes impossible, and disputes appear, a switch happens: conventional action is not enough, and the actors start referring to general principles to solve the disputes. The regime of the plan gives way to the regime of justification. 
For Thévenot, it can be said, these regimes of engagement are hierarchically ordered in two different ways: they exist on different levels of generality as well as on different levels of publicity. Public justifications operate at both the most general and the most public level. Thus, there is, in addition to the 'qualitative' difference (in abstractness) between these regimes, a kind of 'quantitative' difference (in publicity) as well. The three regimes have different cognitive bases, and different goods they are used to foster, but they also differ in terms of how general they are. It is not only that the regime of publicly justifiable action is based on general principles, it is also that it is explicitly more 'general' - in the sense of most directed towards public affairs (Thévenot 2001: 66 \& 79, Thévenot 2007: 415-417). This conflation of generality and publicity creates the inherent problems of the theory. As we shall see from empirical research, arguments based on individual interests can have at least as public and as legitimate roles in debates and disputes as those based on general interests.

\section{Generality and publicity in grammars of commonality}

Next, I shall take a closer look at the grammars of commonality, at how these engagements are generalised from cognitive formats to ways of supporting community and settling disputes in the public sphere. Despite their different orientations towards the public (Thévenot 2007:417), all the regimes can be made into more public entities. When Thévenot refers to the public, he often uses the word commonality (see 2015, footnote 1), precisely because the regime of familiarity does not easily lend itself use in the public sphere (in the sense of newspapers, parliaments, intellectual discussions) - he even consciously turns away from using phrases like 'public space of communication' (2014:16). While this is precise and analytically forceful, it also has the effect of highlighting the community-building aspects of dispute-solving over and above the kind that happens in complex societies and mediatised debates. If one tries to create a version of the theory that is more readily operationalisable in public democratic discussions, publicity has to be confronted head-on. Ylä-Anttila and Luhtakallio (2016) have developed the grammar of public justifications into an analytical tool for understanding public debates. The same, in a way, needs to be done for the other two grammars. ${ }^{5}$

A regime of engagement is transformed into a grammar of commonality in the plural through communicating - that is, making things common for the whole community -

\footnotetext{
5 This article is only concerned with the regime of planned action and the ensuing grammar of liberal
} individuals. 
and composing, settling conflicts and fitting multiple viewpoints, interests and justifications into a (more or less) cohesive whole (Thévenot 2014;9, 2015:85). When engagements are enlarged into grammars of commonality, rather private cognitive models of thinking are transformed into communal, and political, ways of evaluating arguments - thus creating modes of valuation (Centemeri 2014, Eranti 2017, Lamont 2012).

If grammar is understood as a mode of valuation, it is also a system describing legitimacy: the operation of delimiting between the valuable and the not valuable, and defining precisely how valuable things are, is necessarily done based on some kind of criteria. These criteria end up defining which arguments are legitimate in a grammar. This logic opens up the possibility of empirical research into this type of argumentation: when looking at which arguments are seen as legitimate by the actors in a given situation or context, we can decipher which grammar is dominating the situation.

When moving from the personal level towards the public, the regime of familiarity becomes grammar of close affinities, which is a delicate matter: how to communicate these private arrangements and personal attachments in a way that is meaningful to anyone besides the speaker? It is possible, but obviously the nature of the public sphere (Habermas 1991) severely limits these possibilities (see Ylä-Anttila 2016). Blok \& Meilvang (2014) have used the level of familiar engagements to highlight the problems political actors have in presenting knowledge created in and relevant to the familiar format and using it in public discussion in the context of local land-use disputes.

Lonkila (2011, also Gladarev \& Lonkila 2013) has a fine depiction of St. Petersburg park activists who refer to particular trees as their brothers. They oppose felling the trees, not because of the abstract principles of any common good, but because the trees are really meaningful to them, because they are emotionally attached to these trees. And YläAnttila (2016) shows how a cultural symbol with strong emotional resonance can, even in public discussions, be appropriated for populist political use. This political use derives its power precisely from this strong relationship and familiarity.

However, as mentioned previously, when rising above the cognitive level and towards the general level, two things happen simultaneously: we rise in terms of abstraction, and we rise in terms of publicity. The effects of these two movements are different for different grammars. In what follows, I focus on the regime of engagement in the plan and the 
liberal grammar, and what happens to them if we rise above small communities and look at them from the perspective of the body politic (or some other larger community).

Engagement in the plan describes aspiring towards goals, choosing the means of reaching those goals, 'projecting yourself in the future' (Thévenot 2007). The basis of the grammar of liberal individuals in public (Thévenot 2011, 2014, and 2015) is to state individual interests as preferences, in such a way that any actor could take these positions (Thévenot 2015:90, Cheyens 2011, 2014). In this grammar, Thévenot's notion of composing, of gathering into some kind of whole individual interests which might possibly contradict each other, is most relevant. This is because it tells us what disputes and conflict resolution between such preferences are like: trades, negotiations, personal items pushed aside. They are expressed as individual choices or interests. Consequently, criticism is only allowed to a lesser degree. 'The integration of differences is achieved by negotiation and bargaining between "stakeholders"' (Thévenot 2014:17).

This grammar clearly grasps something relevant about public goods and arguments, especially when compared with public justification: not all arguments build on an expressed or explicit idea of the common good. Some people are publicly only worried about themselves and their monetary well-being, while other people value deals and a plurality of opinions more than agreement or even than the possibility of implementing the general will. Here an empirical example, taken from a land-use participation case, might help. In land-use disputes, many residents of the contested parts of the city are explicitly and solely concerned about their own properties and backyards - or those of their immediate communities. This can be seen in the following quotation from Helsinki, which was sent by a resident to the city planning administration in response to a proposed urban change:

If all of [the proposed changes] really become reality, I shall pack up my family and move to greener and lusher surroundings. When I discuss this with my friends here at this part of city, they all say the same.

The resident sending this letter is clearly taking part in a (semi-)public discussion - but justifications are nowhere to be seen. This mode of making direct reference to the individual interest of the actor is seen as less general than referencing common goods, or justifications. This shows in Thévenot's own comparative work: in France, individuals and references to 
individual preferences were seen as illegitimate in public discussion (Moody \& Thévenot 2000, Thévenot \& Lamont 2000). ${ }^{6}$

The same research (ibid.) also shows that this feature of legitimacy is not universal. In the US, it was seen as a completely ordinary way of presenting political claims. But even there, one can ask when reference to the good of a finite number of people turns from a private interest to the common good (as is done in Moody \& Thévenot 2000, Thévenot \& Lamont 2000)? How many people do you need for the common good? In land-use disputes, residents routinely argue on the basis of their own interests, and even that of the neighbourhood or small group (see Eranti 2017, Richard-Ferroudji 2011). So here we have a problem of legitimacy and generality: how to construct legitimacy that is not based on common goods and the general will? And we also have a problem of representation and the level of the collective actors: in public discussions, private interests are often used as the principal mode of argumentation, that is, as the principal grammar. And not only by individuals, but also on the part of collectives, and, even more often, individuals who claim to represent a collective.

So although it can be said that the level of generalisation is higher for the publicly justifiable action, since it must be formatted in a way that is compatible with the common good, it would be quite hard to show that argumentation based on the grammar of liberal individuals is somehow less oriented towards the public.

The problems with hierarchical levels of generality become visible when moving from dealing with cognitive formats to dealing with public (or semi-public) agreements or disagreements - when moving from cognition and relationship to objects to arguments made in the public polity. ${ }^{7}$ When working on an interactional scale, it is easy to see continuous normal action, planned action and personal interests as intimately linked. But when focus is broadened to a more generalised arena, the link between unproblematised 'normal' action,

\footnotetext{
${ }^{6}$ Regarding the all-encompassing nature of On Justification: of course all arguments possible could be interpreted as being somehow about the common good - voicing private interests could be seen as tacitly endorsing market worth, or only being a different mode of civic justification and so on. This however comes dangerously close to sloppy psychologising, since from public, written sources, we would be hard-pressed to argue that a certain cognitive process was behind the argumentation, perhaps even unbeknownst to the speaker herself. I suggest that a more substantial interpretation of certain arguments can be arrived at by defining them in different terms, and that the categories presented in On Justification are better utilizsed if they are used only as references to the common good (in relation to the concept of general will.)

${ }^{7}$ It is entirely possible that these problems only manifest themselves when we look at the public or semi-public level of politics, and do not present themselves in, for example, ethnographic research, or in other situations more directly linked to individuals in cognitive situations.
} 
and having one's own primarily self-interest in mind becomes much more iron-clad and problematic than it necessarily should be. Despite what Thévenot writes (2015: 84), this move can have precisely the effect he tried to avoid: that of naturalising the link between private interests and the individual's normal action.

When we move on to analysing participation and argumentation on the level of society, and thinking about deliberative democracy, we run into problems. If we look at material produced by citizens using established participatory channels, such as the example used in this article, all we have is the faintest of trace of thought-process, the words trailing on the paper. A researcher cannot postulate, at least not with any great certainty, the mental states or cognitive formats of these authors. We need a version of the liberal grammar that is independent of ideas of cognitive styles, and that incorporates the notion of the public from the start.

Thus we cannot rely too much on the (assumed) regimes of engagements. The engagement model is based on the actor's own internal evaluation: what is the format in which information is processed, how are public guarantees used, and so on. But we have to base our analysis on external factors if we want to understand what is actually happening in the world. To sum up: it is unclear how helpful the grammar of individuals operating in a liberal public is in analysing disputes on a broader level than in local community. This is partly because of the problems created by conflating generality and publicity, and partly because the criterion for the legitimacy of the argumentation has not been clearly defined.

\section{The grammar of individual interests}

In what follows, I present a reconstruction of the 'grammar of individuals in a liberal public' (Thévenot 2014, 2015), contrasting it primarily with the grammar of public justification and its model of the common good. Since this theoretical reconstruction is carried out in order to develop tools for analysing democratic participation and public discussion, examples and parallels from theories of deliberative theory and participation studies are presented.

When viewed through the regimes of engagement, the common good, constructed by utilising the general will, will always be the most abstract and most public. From the point of view of democratic participation in (possibly mediatised) disputes, this does not do justice to the specific functions of the grammar of individual interests: it is based on a different idea of how the common good (and thus the general will) works. 
It can be said that in the grammar of public justification, the explicit aim is to discuss and debate foundational ideas. This happens by referencing common goods - general principles. These general principles always argue about the good for all. This might not be exactly the same as arguing about the general will, but it certainly comes close. Thus, the model of public justification is a model of deliberation: situations are formulated as conflicts between different public goods, compromises between them are made, and in the end, the polity as a collection of rational actors comes to an informed decision (conflicts can naturally also happen among common goods - but they are more easily solved through reality tests). It is implied that the theoretical model for this decision is unanimous. (Here it is perhaps useful to think of deliberative democracy in terms such as those used in Polletta 2008, or Young 1996.)

The grammar of public justification is linked with the concept of the sovereign: deliberation - between shared formulations of the common good - is about finding an agreement on the general will, which then works as the basis for applying sovereign power. ${ }^{8}$ This sovereign, earlier personified by the monarch, is usually an abstract description of the state. But a concrete example to highlight the idea of the sovereign is the following: within urban planning, this sovereign power lies within the city planning authority. It ultimately makes all the decisions in city planning, in conjunction with the democratically elected councillors. Thus, the residents who are arguing against planning changes using the grammar of public justification are trying to win the support of the sovereign: to prove that their position is what is good for everyone, not just for themselves (see eg. City of Helsinki 2015).

In the grammar of individual interests, in order to make a legitimate claim, an actor must construct a subject that can legitimately argue its interests - and then nominate herself as the legitimate representative of that subject. The general will is not assumed to be a transcendent property of a sovereign entity, but is composed of all the individual wills - all interests and wills are legitimate and relevant (cf. Young 1996, 126-128, Rosanvallon 2013, 274-276.). Emmanuelle Cheyns has shown that precisely this construction of the legitimate subject is also where the grammar of individual interests can fail, when the legitimacy of the actor is disputed $(2011,2014)$.

\footnotetext{
${ }^{8}$ See Rousseau 1762 for The Social Contract, discussion on it in On Justification: 107-111, Baczko 1988 on the social contract and the French revolution, Young 1996 and Benhabib 1996 on deliberative democracy contrasted with interest-based or aggregative democracy, and Rosanvallon 2013 for the legitimacy of interest-based democracy.
} 
The prototypical case of subjects' legitimate interests is the idea of the referendum. Without any regard to the reason or justification behind individual votes, each citizen as a rights-carrying subject chooses one of the options on the table, and the idea with most votes wins. In a referendum, the sovereign acts based on votes, not based on arguments. The deliberation involved is a separate action from the actual decision (see Baczko 1988, Young 1996, 120-121, Rosanvallon 2013).

What is implied is the legitimacy of differing opinions and claims, even in the absence of justifications. This does not mean that the level of generality or generalisability is necessarily lower than in positions justified using orders of worth - and at the very least, the level of publicity certainly is not lower. Whereas the generality in public justification comes through principles - arguments are always about what the common good is - the generalisation in the grammar of individuals could be said to come through the construction of the subject as a group of people sharing an opinion. While the general model is based on the idea of individuals as subjects with claims, interests, and individual wills, these subjects can also be constructed as larger bodies (Moody \& Thévenot, 2000, Self-reference 1).

The difference in collectives between the civic order of worth and the grammar of individual interests is that the latter operates without the notion of supressing your own will for the good of the collective that is evident both in the civic order and in the grammar of public justification. These are opt-in communities, communities of preferences. The legitimacy of this kind of constructed subject is an interesting question that is explored by Rosanvallon (2013), and is not pursued further here. ${ }^{9}$

To show how these subjects are created, and how their interest is argued, I shall take an example. In the comment letters sent to the city planning authority about an imminent planning change, many residents of Haaga, a neighbourhood in Helsinki, constructed 'the people of Haaga' as the de facto writer of their comment letters, as in the following example:

Hey. I'd like to express my opinion on this matter. Haaga is already dense enough as it stands. Once the green areas are refurbished and a new park building is built to replace the old one, it's enough. (...) And we don't want more traffic on our streets.

\footnotetext{
${ }^{9}$ And at the same time, the rules of the political culture are not identical for everyone. While Everyman might well say 'I'm only in it for my own backyard,' that same option is not available to the more public members of the community, such as politicians and representatives - at least not in same capacity. The same is true for publicity: it might well be that we hope that the world might be a place where everyone's first thought would be for the common good, and that is why newspapers and public officials are probably expected to present these justifications more prominently.
} 
The implied argument is that 'the people of Haaga' is a political subject that a) can legitimately comment on whether new housing should be built in the forest near the current Haaga, and that b) the opinion of this subject is unanimously against the new development. The residents were able to represent this subject in the media and act as a unified actor in opposition to the plan. (See Alapuro [2010] and Bourdieu [1991] for analysis of this kind of representation among political actors and voluntary associations; this constructed representation can also be seen as an act of dominance, dispossessing the people whom the actor claims to represent.)

The subject of 'people of Haaga' is inclusive, but with two conditions: to join it, one must 1) share the opinion, and 2) be from Haaga (this latter is not as strict: membership is not dependent on personal experience and relationship, as it would be in the grammar of close affinities). In this example, this subject is both an existing thing and a fiction: these subjects overplay both their popular support and the unanimity of the people. The majority of the 'people of Haaga' have not participated in any kind of discussion.

Since the grammar of individual interests is based on the idea that the general will is a sum of individual wills, all individual positions can be legitimately expressed. Whereas the grammar of public justification requires a higher common principle to be used in the evaluation, in the grammar of individual interests, small groups can present their positions, their individual wills, and still be treated as individuals, not collective actors in the sense of the civic worth.

Here I have suggested changing the name of the grammar from grammar of individuals in a liberal public to the grammar of individual interests. There are two main reasons for this: 1) the new name would omit direct references to liberalism. The connection has always relied more on implicit divergence from certain uses of the word than on explicit engagement with the (English-language) body of philosophical literature. As liberalism can be found in many forms, it would perhaps be safer not to carry its full baggage within the grammar. 2) The formulation here is specifically aimed at understanding more public, more deliberative processes than cognitive/practice-level processes.

\section{Grammar of individual interests in action}

One of the greater imbalances in the sociology of engagements has been the differing levels of explication between the three regimes and grammars. Earlier I tried to show how we could think about the grammar of individual interests as both legitimate and oriented towards the 
public. In what follows, I present vignettes about what the grammar of individuals is on the substance level. Here it helps to think of it as a cultural repertoire (Swidler 1986) in much the way justifications have been examined (Silber 2003).

Rosanvallon (2008: 25-26) divides suspicion and opposition against elected or otherwise ruling political organs into two main branches. The first suspicion is suspicion of the ability of elected or chosen leaders or planners to fulfil, express and implement the general will. The other suspicion, a more fundamental form of what he calls counterdemocracy, is based on what 'a liberal disbelief' about whether the general will exists at all (ibid.). The central idea is to protect the individual and her interests against the central planner or decision-maker. This is one formulation of the grammar of individual interests. These two different types of suspicion have been said to be exemplified respectively by European and American-style liberal political systems (Moody and Thévenot, 2000; Thévenot, Moody and Lafaye, 2000, Lamont \& Thévenot 2000).

Within the urban planning literature, the NIMBY (Not In My Backyard) argument has been the focal concept for discussions on the tension between the common good and private interests. The (few) examples in this paper also come from this literature. Many analyses of NIMBY conflicts are rooted in the idea of the private interests of individuals (Freudenberg and Pastor 1992, Gibson 2005, Moody and Thévenot 2000, Wolsink 2006). Even though the general model of the grammar of individual interests is the referendum, negotiations and discussions are also part of the repertoire. These discussions are not deliberations on the relative merits of common goods, but rather trading, haggling, and the presentation of individual situations and subjectivities. On the rhetorical level, the actors make demands, broker deals and issue ultimatums rather than argue about principles on the general level (Thévenot 2007, 2014, 2015, Moody and Thévenot, 2000, Thévenot, Moody \& Lafaye, 2000). In participation in city planning, planning officials see the value of comments and participation by individuals for providing contextual information, or subjective opinions, on how a planning change specifically affects their lives (Bäcklund 2007 158-170). Personal opinions and individual comments are valued not despite their being personal and individual, but because they are.

Many formulations of politicisation (see Luhtakallio 2012, 12, 170-190) are built around the idea of a rise in generality. This rise in generality has usually been seen as a move to a more abstract level, and that has usually meant moving from one's own private interest 
towards the common good. Since we already know that this is not the only way to present legitimate political claims, we shall need to modify the thinking around this rise in generality. Luhtakallio underlines the fact that 'the recognition of the possibility of conflict is central to politicisation' (ibid. 186, see also Palonen 2003: an issue becomes political once it is playable). This conflict need not be a conflict between principles, it can also be a conflict of interests (between, not within, individuals). Thus we could enlarge our ideas about politicisation: we could also think about rises in publicity (making something public, making preferences or principles well-known also opens issues as playable), and the construction of political subjects (creating, on a rhetorical level, communities which to present a claims-maker as legitimate).

To sum up: in the grammar of individual interests, the common good is seen to rise out of the private interests of relevant actors - not by finding a single good, but through the articulation (and contestation) of preferences by legitimate actors. The actors are legitimate if they are able to present their preferences as if drawn from a publicly available pool of options. These actors may be individuals or constructed community-level political subjects. In public discussions, the central rhetorical move is to construct the interest-holding actor - such as a smaller community within a city - and claim to represent this community. These are opt-in communities of preferences: all that is needed for membership in them is to accept the interest as it is presented. Since these interests are not articulated as principles, they can be adopted, discarded, haggled over, and eventually compromised (cf. Polletta 2008).

\section{Conclusions}

The purpose of this article has been to investigate and slightly re-formulate Laurent Thévenot's theory of grammars of communality. The aim was to end up with a theoretical system that would allow research on public discussions, participation, and other ways through which democracy happens in public settings. Its main concern has been the grammar of individual interests, which I argue should be treated as being potentially as public as the grammar of public justification. I also suggest that it would be more fruitful to argue that the level of abstraction in the grammar of individual interests is not lower as such, but rather that the abstraction is built on different grounds. This helps to distinguish between legitimate and illegitimate uses of the grammar.

We now have a concept of how democratic discussion, that is, conflict resolution and goal-setting in a complex society, might work. It includes three possible higher-level 
scales of evaluation: one based on actors pursuing their self-interest, one based on common goods, and one based on intimate relations between people and the material world. In addition to this, the grammar of common goods is defined by conflicts over the very definition of the common good, conflicts between common goods, and conflicts over measurement within the common goods. Conversely, the grammar of individual interests is defined by conflicts between generalisable interests of individuals, and the grammar of private affinities over strong emotional attachments. These can all be used to justify political positions, even though the term 'justification' has been reserved for situations where common goods are referenced. And all of them can be thought as (sets of) cultural repertoires. This threefold interpretation of justification is presented in table 1 below.

\section{Grammar of Communiality \\ Defining Conflicts}

Nature of the Community

\section{Common Good}

Multiple common goods

1) Over definition of common good

2) over situationally relevant common good

3) over measurement within a definition

$$
\text { General }
$$

Defined by State Humankind
Individual Interest

Self-interest of actors

1) Between interests

2) Over construction of legitimate collective subjects

3) over representation within the collective

Opt-in

Preference-based Ad-hoc
Close Affinities

Intimate and emotional connections

1) Over generalizing private attachments

2) over inclusion into community

3 ) over symbols and commonplaces

Particular Based on Familiarity and sharing Exclusive

The argument presented here does not radically conflict with the spirit in which the theory of grammars of commonality is written. But it highlights the importance of the idea of individual interests as a (somehow, somewhere) legitimate mode of presenting critique - at least in a pragmatic way: it is what people do. Constructing the grammar without referencing engagement in a plan also highlights the idea of representation and political (collective) subjectivity as paramount to the legitimacy of argumentation in the grammar of individual interests. Thus, it may forge a way for us to better understand the pluralism of argumentation and the pluralism of grammars at the level of polity. 


\section{References}

Alapuro, Risto (2010) Conclusion: How history matters in putting Nordic associations in a European perspective. In Alapuro \& Stenius (eds) Nordic associations in a European perspective. Baden-Baden: Nomos.

Baczko, Bronislaw (1988) The Social Contract of the French: Sieyes and Rousseau. The Journal of Modern History 60, supl.:98-125.

Benhabib, Seyla (1996) Toward a deliberative model of democratic legitimacy. In Benhabib (ed): Democracy and difference. Contesting the boundaries of the political. Princeton: Princeton University Press.

Blok, Anders, and Marie Leth Meilvang (2014) Picturing Urban Green Attachments: Civic Activists Moving between Familiar and Public Engagements in the City. Sociology 1-19.

Boltanski, Luc and Thévenot, Laurent (1999) The Sociology of Critical Capacity. European Journal of Social Theory 2(3): 359-377.

Boltanski, Luc and Thévenot, Laurent (2006[1991]) On Justification. Economies of Worth. Princeton and Oxford: Princeton University Press.

Boltanski, Luc (2011) On Critique. A Sociology of Emancipation. Cambridge: Polity Press.

Bourdieu, Pierre (1991) Political representation. In Bourdieu \& Thompson (eds) Language and symbolic power. Cambridge: Polity.

Bäcklund, Pia (2007) Tietämisen politiikka. Kokemuksellinen tieto kunnan hallinnassa. Helsinki: Helsingin kaupungin tietokeskus.

Cheyns, Emmanuelle. (2011). Multi-stakeholder Initiatives for Sustainable Agriculture : Limits of the "Inclusiveness" Paradigm. In Ponte, S., Vestergaard, J. \& Gibbon, P. (eds.) Governing through standards: Origins, drivers and limits, London: Palgrave, pp. 318-354.

Cheyns, Emmanuelle (2014). Making "minority voices" heard in transnational roundtables: the role of local NGOs in reintroducing justice and attachments. Agriculture and Human Values 31(3), 439-453.

Eranti, Veikko (2017) Re-visiting NIMBY: From conflicting interests to conflicting valuations. The Sociological Review, 65 (2), 285-301.

Eranti, Veikko (2016) Individuals Doing Politics: Urban participation, social media campaigning and online nano-politics. Doctoral dissertation. Publications of The Faculty of Social Sciences 28, University of Helsinki, Helsinki. Available at https://helda.helsinki.fi/handle/10138/167721.

Eranti, Veikko (2014) Oma etu ja yhteinen hyvä paikallisessa kiistassa tilasta. Sosiologia 51(1), 21-38.

Freudenberg W and Pastor S (1992) NIMBYs and LULUs, stalking the syndromes. Journal of Social Issues 48(4), 39-61.

Gibson Timothy A (2005) NIMBY and the Civic Good. City and Community 4(4), 381-401.

Gladarev, Boris and Lonkila, Markku (2013) Justifying civic activism in Russia and Finland. Journal of Civil Society 9(4): 375-390.

Habermas, Jürgen (1991) The structural transformation of the public sphere: An inquiry into a category of bourgeois society. Cambridge: MIT press.

Koopmans, Ruud \& Paul Statham (1999) Political Claims Analysis: Integrating Protest Event and Political Discourse Approaches. Mobilization 4:2, 203-211.

Lafaye, Claudette and Thévenot, Laurent (1993) Une justification écologique?: Conflits dans l'aménagement de la nature. Revue Française de Sociologie, 34(4): 495-524. 
Lamont, Michele (2012) Toward a Comparative Sociology of Valuation and Evaluation. Annual Review of Sociology 38(21): 201-221.

Lamont, Michele \& Thévenot, Laurent (2000) Introduction. In Lamont \& Thévenot (eds.) Rethinking comparative cultural sociology: Repertoires of evaluation in France and the United States. Cambridge: Cambridge University Press.

Lonkila, Markku (2011). Yhteisyyden kieliopit helsinkiläisessä ja pietarilaisessa kaupunkiaktivismissa. Sosiologia 48:1.

Luhtakallio, Eeva, \& Ylä-Anttila, Tuomas (2011). Julkisen oikeuttamisen analyysi sosiologisena tutkimusmenetelmänä. Sosiologia 48:1.

Luhtakallio, Eeva (2012) Practicing Democracy. Local Activism and Politics in France and Finland. Basingstoke: Palgrave Macmillan.

Moody Michael and Thévenot, Laurent (2000) Comparing models of strategy, interests, and the public good in French and American disputes. In Lamont M and Thévenot L (eds) Rethinking comparative cultural sociology: Repertoires of evaluation in France and the United States. Cambridge: Cambridge University Press.

Palonen, Kari (2003) Four Times of Politics: Policy, Polity, Politicking, and Politicization. Alternatives 28: 171-86.

Polletta, Francesca (2008) Just Talk : Public Deliberation After 9 / 11. Journal of Public Deliberation $4(1)$.

Richard-Ferroudji, Audrey. (2011). Limites du modèle délibératif: Composer avec différents formats de participation. Politix, 24, 161-181

Ricœur, Paul (2000) The Just. Chicago and London: The University of Chigo Press.

Rosanvallon, Pierre (2008) Vastademokratia. Politiikka epäluulon aikakaudella. Tampere: Vastpaino.

Rosanvallon, Pierre (2013) Demokraattinen oikeutus. Puolueettomuus, refleksiivisyys, läheisyys.

Tampere: Vastapaino

Rousseau, Jean-Jacques (1762) The Social Contract.

Silber, Ilana F (2003) Pragmatic Sociology as Cultural Sociology: Beyond Repertoire Theory?" European Journal of Social Theory 6(4):427-49.

Swidler, Ann (1986) Culture in Action: Symbols and Strategies. American Sociological Review 51(2): 273.

Thévenot, Laurent (2001) Pragmatic Regimes Governing the Engagement with the World. In Theodore R. Schatzki, Karin Knorr Cetina \& Eike Von Sevigny (eds) The practice turn in contemporary theory, 5673. London:Routledge.

Thévenot, Laurent (2007) The plurality of cognitive formats and engagements. Moving between the familiar and the public. European Journal of Social Theory 10(3): 413- 427.

Thévenot, Laurent (2011) Oikeuttavuuden rajat. Yhteiselämää koossapitävät sidokset ja niiden väärinkäyttö. Sosiologia 48:1. Translated by Veikko Eranti

Thévenot Laurent (2014) Voicing concern and difference: from public spaces to common-places. European Journal of Political and Cultural Sociology, 1(1), 7-34.

Thévenot Laurent (2015) Bounded Justifiability: Making commonality on the basis of binding engagements. In Dumouchel P and Gotoh R (eds) Social Bonds as Freedom. Revisiting the Dichotomy of the Universal and the Particular New York, Oxford: Berghahn books. 
Thévenot, Laurent \& Lamont, Michele (2000) Conclusion. In Lamont \& Thévenot (eds) Rethinking comparative cultural sociology: Repertoires of evaluation in France and the United States. Cambridge: Cambridge University Press.

Thévenot Laurent, Moody Michael and Lafaye Claudette (2000) Forms of Valuing Nature: Arguments and Models of Justification in French and American Environmental Disputes. In Lamont, Michelle and Thévenot, Laurent (eds) Rethinking comparative cultural sociology: Repertoires of evaluation in France and the United States. Cambridge: Cambridge University Press.

Wagner, Peter (1999) After Justification: Repertoires of Evaluation and the Sociology of Modernity. European Journal of Social Theory 2(3):341-57.

Walzer, M. (1983). Spheres of justice: A defense of pluralism and equality. Basic Books.

Wolsink, Maarten (2006) Invalid theory impedes our understanding: a critique on the persistence of the language of NIMBY. Transactions of the Institute of British Geographers 31(1): 85-91.

Young, Iris Marion (1996) Communication and the Other: Beyond Deliberative Democracy. In Selya Benhabib (ed.) Democracy and Difference. Princeton: Princeton University Press.

Ylä-Anttila, Tuomas. (2010a). Pragmatistinen näkökulma yhteiskunnallisiin liikkeisiin. Sosiologia 46(4).

Ylä-Anttila, Tuomas (2010b) Politiikan paluu. Globalisaatioliike ja julkisuus. Tampere: Vastapaino.

Yla-Anttila, Tuomas., \& Kukkonen, A. (2015). How arguments are justified in the media debate on climate change in the USA and France. International Journal of Innovation and Sustainable Development, 8(4), 394-408.

Ylä-Anttila, Tuomas and Luhtakallio, Eeva (2016) Justifications analysis: Understanding moral evaluations in public debates. Sociological Research Online 21 (4).

Ylä-Anttila, Tuomas;Vesa ,Juho; Eranti, Veikko; Luhtakallio, Eeva; Lonkila, Marku and Kukkonen, Anna (forthcoming) Up with Ecology, Down with Economy? The Consolidation of the Idea of Climate Change Mitigation in the Global Public Sphere.

Ylä-Anttila, Tuukka (2016) Familiarity as a tool of populism. Political appropriation of shared experiences and the case of Suvivirsi. Acta Sociologica Online first, available at http://journals.sagepub.com/doi/abs/10.1177/0001699316679490. 